\title{
Video Pembelajaran Kontekstual pada Topik Daur Hidup Hewan dan Upaya Pelestariannya untuk Kelas IV SD
}

\author{
Ketut Dwi Ulan Dewi ${ }^{1}$, I Gede Astawan², Alexander Hamonangan Simamora ${ }^{3}$
}

1,2,3 Jurusan Pendidikan Dasar, Universitas Pendidikan Ganesha, Singaraja, Indonesia

\section{A R T I C L E I N F O}

\section{Article history:}

Received July 26, 2021

Revised July 30, 2021

Accepted September 30, 2021

Available online October 25, 2021

Kata Kunci:

Video, Kontekstual, Daur

Hidup Hewan

Keywords:

video, Contextual, Animal Life Cycle

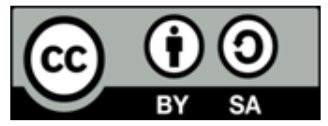

This is an open access article under the CC BY-SA license.

Copyright $(2021$ by Author. Published by Universitas Pendidikan Ganesha.

\begin{abstract}
A B S T R A K
Pembelajaran selama kegiatan belajar dari rumah lebih berfokus pada pemberian tugas. Hal ini dikarenakan kurangnya kemampuan guru dalam memanfaatkan teknologi. Penelitian ini bertujuan untuk menciptakan media video pembelajaran kontekstual pada topik daur hidup hewan dan upaya pelestariannya. Penelitian ini merupakan jenis penelitian pengembangan yang mengacu pada prosedur model ADDIE. Subjek uji coba penelitian yaitu 2 orang ahli isi pelajaran, 2 orang ahli media pembelajaran, 2 orang ahli desain pembelajaran, 2 orang praktisi, 6 orang siswa untuk uji coba perorangan, dan 12 orang siswa untuk uji coba kelompok kecil. Pengumpulan data penelitian ini menggunakan metode wawancara, dan kuesioner. Instrumen pengumpulan data yang digunakan adalah ratting scale. Teknik yang digunakan untuk menganalisis data yaitu teknik analisis deskriptif kualitatif dan kuantitatif. Data hasil validitas dihitung menggunakan rumus mean untuk mengetahui rata-ata skor validitas media. Berdasarkan hasil penelitian yang telah dilakukan, ratarata skor validitas video pembelajaran kontekstual dari segi ahli isi sebesar 3,8 (sangat baik), dari segi ahli media sebesar 3,83 (sangat baik), dari segi desain sebesar 3,67 (sangat baik), dari segi praktisi sebesar 3,94 (sangat baik), skor yang diperoleh dari uji coba perorangan sebesar 3,95 (sangat baik), dan uji coba kelompok kecil sebesar 3,81 (sangat baik). Berdasarkan hasil analisis tersebut, video pembelajaran kontekstual pada topik daur hidup hewan dan upaya pelestariannya dinyatakan valid dan layak digunakan dalam proses pembelajaran.
\end{abstract}

\section{A B S T RACT}

Learning during learning from home activities is more focused on giving assignments. This is due to the lack of teachers' ability to use technology. This study aims to create contextual learning video media on the topic of animal life cycles and conservation efforts. This research is a type of development research that refers to the ADDIE model procedure. The subjects of the research trial were 2 subject matter experts, 2 instructional media experts, 2 instructional design experts, 2 practitioners, 6 students for individual trials, and 12 students for small group trials. This research data collection using interview methods, and questionnaires. The data collection instrument used is a rating scale. The technique used to analyze the data is descriptive qualitative and quantitative analysis techniques. Data validity result were calculated using the mean formula to determine the average media validity score. Based on the results of the research that has been carried out, the average validity score of contextual learning videos from the content expert point of view is 3,8 (very good), from the media expert point of view of 3,83 (very good), in terms of design of 3,67 (very good), from the practitioner's point of view of 3,94 (very good), the score obtained from the individual trial was 3,95 (very good), and the small group trial was 3,81 (very good). Based on the results of the analysis, contextual learning videos on the topic of animal life cycles and their conservation efforts are declared valid and suitable for use in the learning process.

\section{PENDAHULUAN}

Pandemi Covid-19 telah mentransformasi tatanan kehidupan dan telah memberikan dampak yang sangat besar di segala bidang kehidupan (Abidah et al., 2020; Giatman et al., 2020; Lapitan et al., 2021). Salah satu bidang yang sangat merasakan dampak dari guncangan wabah pandemi Covid-19 ini adalah bidang pendidikan. Dibidang pendidikan, proses pembelajaran yang semula dilaksanakan secara tatap muka, kini harus dilaksanakan secara daring (dalam jaringan) (Baber, 2021; Dhawan, 2020; Shah et al., 2021). Pembelajaran yang dilaksanakan secara daring mengakibatkan sarana pembelajaran yang digunakan tidak bisa terhindar dari 
teknologi, sehingga mau tidak mau semua elemen penting dalam dunia pendidikan harus mempersiapkan diri menggunakan fasilitas teknologi sebagai syarat utama dalam pembelajaran daring (Batubara, 2021; Mishra et al., 2020). Guru merupakan figur sentral yang memiliki peran penting dalam penyelenggaraan pendidikan yang sangat diperlukan untuk mendorong keberhasilan peserta didik (Makovec, 2018; Sopian, 2016). Sehingga, dalam situasi pandemi ini guru dituntut memiliki kemampuan dalam memanfaatkan teknologi informasi untuk menunjang proses pembelajaran daring (Mastura \& Santaria, 2020; Selvaraj et al., 2021).

Namun kenyataannya, dalam pelaksanaan pembelajaran daring ini terdapat kendala-kendala terkait dengan kesiapan lembaga pendidik dalam melaksanakan pembelajaran daring (Damayanthi, 2020; Lapitan et al., 2021). Kendala-kendala yang sering ditemui dalam peroses pembelajaran daring yaitu terbatasnya kemampuan guru dalam menggunakan teknologi baik dari kemampuan mengakses lebih jauh yang berkaitan dengan internet dan kemampuan mengoprasikan media pembelajaran secara online (Asmuni, 2020; Basar, 2021). Hal ini sesuai dengan hasil wawancara dengan guru kelas IV SD Negeri 1 Tinggarsari dan SD Negeri 3 Tinggarsari yang mengatakan bahwa, karena kurangnya kemampuan dalam memanfaatkan teknologi sehingga dalam proses pembelajaran daring guru menyampaikan materi pelajaran hanya dengan pesan tertulis di grup belajar, serta proses pembelajaran lebih difokuskan pada pemberian tugas. Hal ini mengakibatkan siswa sulit memahami materi pelajaran, sehingga motivasi belajar siswa berkurang dan akhirnya berdampak terhadap hasil belajar siswa yang rendah. Selain itu, berdasarkan hasil wawancara yang dilakukan, didapatkan informasi bahwa terdapat materi pelajaran yang sulit dijelaskan dalam proses pembelajaran daring karena memiliki materi yang bersifat abstrak seperti materi yang ada pada muatan pelajaran IPA. Ilmu Pengetahuan Alam (IPA) merupakan materi yang tidak hanya berupa kumpulan pengetahuan tetapi juga merupakan suatu proses penemuan dan cenderung bersifat abstrak (Hidayah et al., 2018; Tias, 2017). Materi IPA yang bersifat abstrak jika hanya dijelaskan tanpa menunjukkan kejadian secara nyata, maka dapat menyebabkan siswa sulit memahami materinya (Ismiyanti, 2020). Salah satu materi IPA yang perlu dijelaskan secara konkret yaitu materi pada topik daur hidup hewan dan upaya pelestariannya yang ada di kelas IV semester genap. Hal ini sangat sulit untuk membawa sesuatu yang nyata kedalam proses pembelajaran daring, padahal belajar akan lebih bermakna apabila siswa "mengalami" bukan "menghafal" materi pelajaran (Baharuddin, 2020; Muamanah \& Suyadi, 2020). Berdasarkan permasalahan tersebut, perlu adanya solusi untuk membantu guru dalam menyampaikan materi pelajaran dengan lebih jelas dan menarik, sehingga siswa dapat memahami materi pelajaran dengan lebih jelas serta meningkatkan motivasi siswa dalam proses pembelajaran daring.

Adapun solusi yang diberikan untuk mengatasi permasalahan tersebut yaitu dengan mengembangkan media yang menarik dan memanfaatkan teknologi sehingga dapat membantu siswa memahami materi pelajaran. Salah satu media pembelajaran yang memanfaatkan teknologi dan sesuai dengan karakteristik peserta didik adalah media video pembelajaran (Jampel \& Puspita, 2017; Khairani et al., 2019). Video pembelajaran merupakan media yang menyajikan unsur audio dan visual untuk menyampaikan pesan-pesan pembelajaran (Potdevin et al., 2018; Yusup et al., 2016). Penggunaan video pembelajaran akan dapat meningkatkan ingatan siswa karena disajikan dengan audio dan visual, dapat dipelajari kapan dan dimana saja, mudah digunakan, dapat diputar berulang-ulang, memperjelas penyampaian pesan sehingga tidak bersifat verbalistis, serta dapat digunakan oleh kelompok besar maupun individu (Apriansyah et al., 2020; Fauzi et al., 2017; Pal \& Patra, 2020). Video pembelajaran yang dapat mendukung siswa kelas IV belajar materi IPA yang bersifat abstrak yaitu video pembelajaran yang dikemas dengan pendekatan kontekstual. Pendekatan kontekstual merupakan suatu konsep belajar yang mengaitkan antara materi pelajaran dengan siatuasi kehidupan nyata, sehingga siswa tidak akan belajar dengan menghafal melainkan belajar dari pengalaman yang dimiliki (Fadillah et al., 2017; Nawas, 2018). Denggan demikian, pendekatan pembelajaran kontekstual yang dikemas dalam sebuah media video pembelajaran akan dapat membantu siswa kelas IV yang berada pada tahap oprasional konkret untuk memahami suatu konsep secara nyata serta membantu siswa mengaitkan konsep tersebut dengan pemanfaatannya dalam kehidupan sehari-hari sehingga dapat berdampak terhadap hasil belajar siswa.

Berdasarkan temuan penelitian sebelumnya menyatakan bahwa, media video pembelajaran dapat meningkatkan pemahaman siswa terhadap materi pelajaran (Agustini \& Ngarti, 2020; Hidayati et al., 2019). Kemudian, penggunaan videocribe sebagai media pembelajaran dapat meningkatkan motivasi siswa dalam belajar dan membuat pembelajaran menjadi lebih menarik (Pamungkas et al., 2018; Susanti, 2019). Penggunaan video online yang beradaptasi dengan konteks dapat membantu siswa dengan mudah menemukan informasi penting dalam video yang diberikan (Seo et al., 2021). Media video dapat meningkatkan hasil belajar siswa (Arif et al., 2019; Novita et al., 2019). Sehingga, berdasarkan hasil temuan penelitian tersebut, dapat diketahui bahwa penggunaan media video efektif digunakan dalam proses pembelajaran serta memberikan dampak positif dalam proses pembelajaran. Namun, dari temuan penelitian tersebut belum adanya kajian secara mendalam terkait dengan media video pembelajaran kontekstual pada topik daur hidup hewan dan upaya pelestariannya untuk siswa kelas IV SD. Adapun kelebihan media video pembelajaran kontekstual yang dikembangkan dalam penelitian ini yaitu video dikemas secara menarik, materi disajikan secara kontekstual yaitu dengan pemberian ilustrasi nyata, dan bermuatan masalah kontekstual. Selain itu, media video pembelajaran kontekstual dalam penelitian ini juga memberikan ajakan-ajakan untuk menjaga tumbuhan dan hewan yang ada dilingkungan 
sekitar, sehingga secara tidak langsung selain dapat memahami suatu konsep secara nyata, juga dapat menumbuhkan kesadaran akan pentingnya menjaga hewan dan lingkungan. Tujuan penelitian ini adalah untuk menciptakan video pembelajaran kontekstual pada topik daur hidup hewan dan upaya pelestariannya untuk kelas IV SD. Diharapkan melalui media video pembelajaran kontekstual ini dapat membantu guru dan siswa dalam kegiatan pembelajaran baik daring maupun luring, sehingga proses pembelajaran tetap dapat dilaksanakan secara efektis di segala situasi.

\section{METODE}

Penelitian pengembangan media video pembelajaran kontekstual pada topik daur hidup hewan dan upaya pelestariannya untuk kelas IV SD menggunakan tahapan pengembangan model ADDIE. Model pengembngan ADDIE terdiri dari lima tahapan yaituu Analysis, Design, Development, Implementation, dan Evaluation. Pemilihan model ini didasari pertimbangan bahwa model ini dikembangkan secara sistematis (Tegeh \& Jampel, 2017). Adapun bagan tahapan model ADDIE disajikan pada Gambar 1. Namun karena situasi dan kondisi saat ini, serta terbatasnya sumber daya dan waktu sehingga penelitian pengembangan media video pembelajaran kontekstual ini hanya dapat dilaksanakan sampai tahap pengembangan (development).

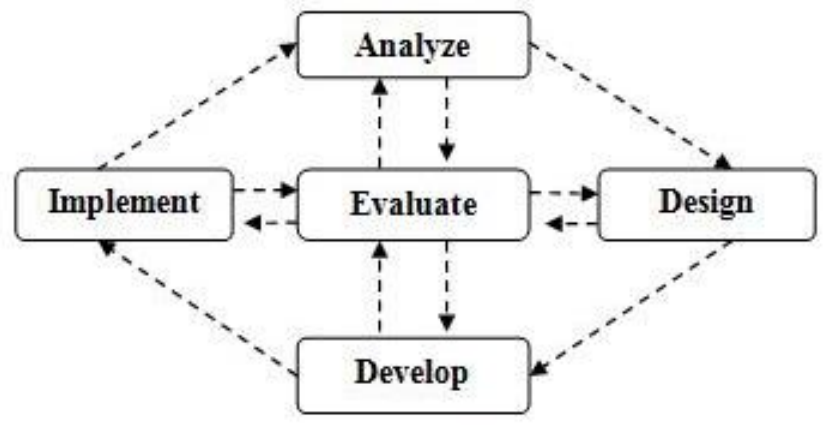

Gambar 1 Tahapan Model Pengembangan ADDIE (Sugihartini \& Yudiana, 2018)

Kegiatan yang dilakukan pada tahap analisis (analysis,) yaitu melakukan analisis kebutuhan dengan cara observasi dan melakukan kegiatan wawancara dengan guru kelas IV SD Negeri 1 Tinggarsari dan SD Negeri 3 Tinggarsari, analisis karakteristik peserta didik dilakukan dengan menganalisis karakteristik siswa kelas IV SD yang dalam hal ini sebagai sasaran pengguna media yang akan dikembangkan, analisis kurikulum dilakukan dengan menganalisis KI, KD, indikator, dan tujuan pembelajaran pada materi muatan pelajaran IPA topik daur hidup hewan dan upaya pelestariannya, analisis media dilakukan dengan mencari informasi terkait dengan karakteristik dan kriteria media pembelajaran yang baik. Tahap perancangan (design) dilakukan dengan membuat rancangan media video pembelajaran kontekstual pada topik daur hidup hewan dan upaya pelestariannya yang berupa rancangan naskah, storyboard, perekaman video green screen, dan mencari hal-hal yang diperlukan dalam proses editing. Tahap pengembangan (development) dilakukan dengan mengembangkan media video pembelajaran kontestual sesuai dengan rancangan yang sudah dibuat. Setelah dilaksanakan pengembangan media, selanjutnya dilakukan uji validitas produk oleh ahli isi mata pelajaran, media, desain, dan dua praktisi, serta delapan belas siswa yang digunakan untuk kegiatan uji coba perorangan dan uji coba kelompok kecil. Setelah melakukan uji validitas produk selanjutnya hasil review tersebut dianalisis dan dilakukan perbaikan terhadap media video pembelajaran kotekstual yang dikembangkan sesuai dengan review dari para ahli, praktisi, dan siswa.

Subjek penelitian pengembangan ini yaitu dua ahli isi mata pelajaran, dua ahli media pembelajaran, dua ahli desain pembelajaran, dua praktisi, serta delapan belas siswa yang digunakan untuk kegiatan uji coba perorangan dan uji coba kelompok kecil. Sedangkan objek penelitian pengembangan ini yaitu valididtas media video pembelajaran kontekstual pada topik daur hidup hewan dan upaya pelestariannya. Jenis data yang digunakan dalam penelitian ini yaitu data kualitatif dan kuantitatif. Metode pengumpulan data yang digunakan dalam penelitian ini yaitu menggunakan metode observasi, wawancara, dan kuesioner/angket. Pada penelitian ini kuesioner yang dibuat akan digunakan untuk mengumpulkan data hasil review uji validitas produk. Pada penelitian ini, instrumen pengumpulan data yang digunakan adalah ratting scale. Ratting scale merupakan penilaian yang didasarkan pada suatu skala tertentu dari skala rendah sampai tinggi misalnya: positif-negatif, besar-kecil. Skala penilaian ratting scale yang digunakan pada penelitian ini menggunakan skala 1-4. Adapun kisi-kisi instrument validasi media video pembelajaran kontekstual pada topik daur hidup hewan dan upaya pelestariannya terdapat pada tabel $1,2,3$, dan 4 . 
Tabel 1. Kisi-kisi Instrumen Ahli Isi Mata Pelajaran

\begin{tabular}{|c|c|c|c|}
\hline No. & Aspek & Indikator & No Butir \\
\hline \multirow[t]{4}{*}{1.} & \multirow{4}{*}{$\begin{array}{l}\text { Kebenaran struktur } \\
\text { materi }\end{array}$} & a. Kesesuaian indikator dengan kompetensi dasar. & 1 \\
\hline & & Kesesuaian tujuan pembelajaran dengan indikator. & 2 \\
\hline & & c. Materi yang disajikan sesuai dengan tujuan pembelajaran. & 3 \\
\hline & & $\begin{array}{l}\text { d. Tujuan pembelajaran sudah menggunakan formatABCD } \\
\text { (Audience, Behavior, Condition, Degree). }\end{array}$ & 4 \\
\hline \multirow[t]{4}{*}{2.} & \multirow{4}{*}{$\begin{array}{l}\text { Keakuratan materi di } \\
\text { dalamnya }\end{array}$} & a. Materi yang disampaikan sudah benar. & 5 \\
\hline & & b. Materi yang disampaikan sudah akurat. & 6 \\
\hline & & c. Materi disajikan berdasarkan fakta yang ada. & 7 \\
\hline & & d. Kebaruan (kemuktahiran) materi yang disajikan. & 8 \\
\hline \multirow[t]{2}{*}{3.} & \multirow{2}{*}{$\begin{array}{l}\text { Kebenaran penyajian } \\
\text { tata bahasa }\end{array}$} & a. Tata bahasa yang digunakan sudah sesuai. & 9 \\
\hline & & b. Penulisan ejaan pada materi sudah tepat. & 10 \\
\hline 4. & $\begin{array}{l}\text { Ketepatan penyajian } \\
\text { tanda baca }\end{array}$ & $\begin{array}{l}\text { a. Penggunaan tanda baca pada materi yang disajikan sudah } \\
\text { tepat. }\end{array}$ & 11 \\
\hline \multirow[t]{4}{*}{5.} & \multirow{4}{*}{$\begin{array}{l}\text { Kesesuaian tingkat } \\
\text { kesulitan materi dengan } \\
\text { pengguna }\end{array}$} & a. Tingkat keluasan materi sesuai dengan karakteristik siswa. & 12 \\
\hline & & $\begin{array}{l}\text { b. Materi awal mampu berkaitan dengan pengetahuan awal } \\
\text { siswa. }\end{array}$ & 13 \\
\hline & & c. Kedalaman materi yang disajikan. & 14 \\
\hline & & $\begin{array}{l}\text { d. Ilustrasi (contoh) dalam media pembelajaran mampu } \\
\text { memperjelas materi yang disampaikan. }\end{array}$ & 15 \\
\hline \multicolumn{2}{|c|}{ Jumlah } & & 15 \\
\hline
\end{tabular}

Tabel 2. Kisi-kisi Instrumen Ahli Media Pembelajaran

\begin{tabular}{|c|c|c|c|}
\hline No. & Aspek & Indikator & No Butir \\
\hline \multirow[t]{4}{*}{1.} & Kualitas visual & a. $\quad$ Gambar yang ditampilkan jelas. & 1 \\
\hline & & b. Animasi yang ditampilkan menarik. & 2 \\
\hline & & c. Teks yang ditampilkan dapat terbaca dengan baik. & 3 \\
\hline & & d. Resolusi video jelas. & 4 \\
\hline \multirow[t]{3}{*}{2.} & Kualitas audio & a. Suara narator jelas. & 5 \\
\hline & & $\begin{array}{l}\text { b. Backsound yang digunakan sudah sesuai dengan suasana } \\
\text { dan tampilan gambar. }\end{array}$ & 6 \\
\hline & & $\begin{array}{l}\text { c. Sound effect yang digunakan sudah sesuai dengan suasana } \\
\text { dan tampilan gambar. }\end{array}$ & 7 \\
\hline \multirow[t]{3}{*}{3.} & Kesesuaian sajian video & a. Pengambilan sudut pandang pada video sudah tepat. & 8 \\
\hline & & b. Kesesuaian antara aspek visual dengan aspek audio. & 9 \\
\hline & & c. Pengaturan durasi video sesuai dengan sasaran. & 10 \\
\hline \multirow[t]{2}{*}{4.} & Kreatif dalam & a. Kemenarikan kreativitas dalam penyajian pesan. & 11 \\
\hline & penuangan ide & $\begin{array}{l}\text { b. Fleksibilitas dalam aspek penyediaan waktu, tempat, } \\
\text { pengajar dan bahan ajar. }\end{array}$ & 12 \\
\hline
\end{tabular}

Jumlah

Sumber: (Supriatna \& Mulyadi, 2009)

Tabel 3. Kisi-kisi Instrumen Ahli Desain Pembelajaran

\begin{tabular}{|c|c|c|c|}
\hline No. & Aspek & Indikator & No Butir \\
\hline \multirow[t]{3}{*}{1.} & Ketepatan & a. Media menyajikan informasi mengenai kompetensi belajar. & 1 \\
\hline & & b. Video yang disajikan sesuai dengan karakteristik siswa. & 2 \\
\hline & & c. Video yang disajikan sesuai dengan karakteristik materi. & 3 \\
\hline \multirow[t]{6}{*}{2.} & Kejelasan metode & Bahasa yang digunakan mudah dipahami siswa. & 4 \\
\hline & & b. Materi yang ada dalam video diuraikan secara efektif. & 5 \\
\hline & & c. Materi yang disajikan dalam video dikemas secara runtut. & 6 \\
\hline & & $\begin{array}{l}\text { d. Media menyediakan evaluasi untuk mengukur pemahaman } \\
\text { siswa terhadap materi pelajaran. }\end{array}$ & 7 \\
\hline & & $\begin{array}{l}\text { e. Materi pada media didasarkan pada situasi kehidupan nyata } \\
\text { siswa. }\end{array}$ & 8 \\
\hline & & $\begin{array}{l}\text { f. Proses pembelajaran pada media dapat memberikan } \\
\text { pengalaman bermakna. }\end{array}$ & 9 \\
\hline
\end{tabular}




\begin{tabular}{|c|c|c|c|}
\hline No. & Aspek & Indikator & No Butir \\
\hline \multirow[b]{3}{*}{3.} & \multirow[b]{3}{*}{ Minat/perhatian } & $\begin{array}{l}\text { g. Proses pembelajaran pada media video diawali dengan } \\
\text { pemberian pertanyaan (questioning). }\end{array}$ & 10 \\
\hline & & $\begin{array}{l}\text { h. Proses pembelajaran pada media video menyajikan refleksi } \\
\text { bagi siswa. }\end{array}$ & 11 \\
\hline & & $\begin{array}{l}\text { a. Video dapat memotivasi dan meningkatkan perhatian siswa } \\
\text { terhadap pembelajaran. }\end{array}$ & 12 \\
\hline \multirow{3}{*}{4.} & \multirow{3}{*}{ Desain pesan } & b. Memudahkan pemahaman siswa terhadap materi. & 13 \\
\hline & & c. Warna gambar nyaman dipandang. & 14 \\
\hline & & d. Ilustrasi dengan materi yang dijelaskan sudah tepat. & 15 \\
\hline \multicolumn{2}{|c|}{ Jumlah } & & 15 \\
\hline
\end{tabular}

Sumber: Walker dan Hess dalam (Arsyad, 2011)

Tabel 4. Kisi-kisi Instrumen Uji Coba Perorangan dan Uji Coba Kelompok Kecil

\begin{tabular}{|c|c|c|c|}
\hline No. & Aspek & Indikator & No Butir \\
\hline \multirow[t]{3}{*}{1.} & Menarik minat siswa & a. Tampilan video pembelajaran menarik. & 1 \\
\hline & & b. Gambar yang ditampilkan menarik. & 2 \\
\hline & & c. Warna yang ditampilkan dalam media video menarik. & 3 \\
\hline \multirow[t]{5}{*}{2.} & Penyajian materi & $\begin{array}{l}\text { a. Materi yang disajikan dalam video pembelajaran mudah } \\
\text { dipahmi. }\end{array}$ & 4 \\
\hline & & b. Contoh yang diberikan dalam materi mudah dipahami. & 5 \\
\hline & & c. Bahasa yang digunakan mudah dipahami. & 6 \\
\hline & & d. Huruf dapat terbaca dengan jelas. & 7 \\
\hline & & e. Materi pada media didasarkan pada situasi kehidupan nyata. & 8 \\
\hline \multirow[t]{2}{*}{3.} & Perhatian dan motivasi & a. Video pemelajaran mampu meningkatkan perhatian. & 9 \\
\hline & & b. Video pembelajaran mampu memotivasi belajar. & 10 \\
\hline \multirow[t]{2}{*}{4.} & Kejelasan suara & a. Suara narator jelas. & 11 \\
\hline & & $\begin{array}{l}\text { b. Musik latar yang digunakan dapat memberikan semangat } \\
\text { dalam belajar. }\end{array}$ & 12 \\
\hline \multicolumn{2}{|c|}{ Jumlah } & & 12 \\
\hline
\end{tabular}

Kisi-kisi instrumen selanjutnya dikonsultasikan kepada dosen pembimbing untuk mendapatkan masukan. Setelah melaksanakan konsultasi dilanjutkan dengan menyusun instrument, kemudian dilakukan uji ahli (judges). Hasil penilaian uji ahli (judges) dihitung dengan menggunakan rumus Gregory untuk mengethaui koefesien validitas isi. Validitas isi instrumen validasi media video pembelajaran kontestual pada topik daur hidup hewan dan upaya pelestariannya yaitu sebesar 1,00 atau berada pada rentang 0,80-1,00 dengan kriteria validitas sangat tinggi. Selain itu, uji reliabilitas juga dilakukan untuk mengetahui keajegam instrumen yang sudah dibuat. Rumus yang digunakan untuk uji reliabilitas yaitu Percentage of Agreement. Reliabilitas instrumen validasi media video pembelajaran kontestual pada topik daur hidup hewan dan upaya pelestariannya yaitu sebesar 1,00 dengan kriteria reliabilitas instrumen sangat tinggi. Metode dan teknik analisis data yang digunakan dalam penelitian ini yaitu metode analisis deskriptif kualitatif dan metode analisis deskriptif kuantitatif. Data yang diolah menggunakan metode analisis deskriptif kualitatif adalah data berupa saran, masukan, tanggapan dan kritik dari hasil review para ahli. Kemudian, metode analisis deskriptif kuantitatif digunakan untuk untuk memeroleh rata-rata skor dari masing-masing ahli melalui lembar penilaian. Skor yang diperoleh kemudian dihitung rata-ratanya untuk mengetahui validitas media yang dikembangkan dengan menggunakan rumus mean. Rata-rata skor yang diperoleh selanjutnya dikonversikan ke dalam pedoman konversi skala 5 untuk mendapatkan hasil validitas media. Adapun pedoman konversi skala 5 disajikan pada Tabel 5.

Tabel 5. Pedoman konversi skala 5

\begin{tabular}{cc}
\hline Rentang Skor & Klasifikasi/Predikat \\
\hline $3,25<\bar{x}<4,00$ & Sangat Baik \\
$2,75<\bar{x}<3,25$ & Baik \\
$2,25<\bar{x}<2,75$ & Cukup \\
$1,75<\bar{x}<2,25$ & Tidak Baik \\
$1,00<\bar{x}<1,75$ & Sangat Tidak Baik \\
\hline
\end{tabular}




\section{HASIL DAN PEMBAHASAN}

\section{Hasil}

Penelitian ini menggunakan prosedur pengembangan model ADDIE. Adapun prosedur tersebut disajikan sebagai berikut. Tahap pertama yaitu tahap analisis (analysis). Pada tahap analisis terdapat empat hal yang dilakukan yaitu analisis kebutuhan, analisis karakteristik siswa, analisis kurikulum dan analisis media. Tahap analisis kebutuhan dilakukan dengan melakukan observasi dan wawancara di SD Negeri 1 Tinggarsari dan SD Negeri 3 Tinggarsari. Berdasarkan kegiatan wawancara yang telah dilakukan, diperoleh informasi bahwa karena kurangnya pemahaman dan pemanfaatan teknologi, sehingga dalam proses pembelajaran daring guru menjelaskan materi pelajaran dengan pesan tertulis di group belajar, serta proses pembelajaran daring lebih berfokus pada pemberian tugas. Selain itu, diperoleh juga informasi bahwa terdapat materi pelajaran yang sulit dijelaskan dalam proses pembelajaran daring karena memiliki materi yang luas dan bersifat abstrak seperti pada materi muatan pelajaran IPA. Jika dilihat dari permasalahan tersebut, maka dibutuhkan sebuah inovasi cara mengajar guru dalam mengajar yakni dengan memberikan media yang inovatif untuk memudahkan guru dalam menyampaikan materi pelajaran seperti media video pembelajaran kontekstual. Kemudian, pada tahap analisis karakteristik siswa didapatkan hasil bahwa siswa yang berada di usia sekolah dasar yaitu 7-11 tahun berada di masa operasional konkret, sehingga untuk memahami suatu konsep pembelajaran siswa membutuhkan bendabenda yang dapat menjelaskan pembelajaran serta penjelasan materi yang dikaitkan dengan situasi nyata yang tidak asing baginya. Analisis kurikulum dilakukan dengan menganalisis KI, KD, indikator, dan tujuan pembelajaran materi muatan pelajaran IPA topik daur hidup hewan dan upaya pelestariannya yang ada di buku Tema 6 Cita-citaku. Adapun hasil dari analisis kurikulum disajikan pada Tabel 6.

Tabel 6. Kompetensi Dasar (KD), Indiktor, dan Tujuan Pembelajaran IPA Topik Daur Hidup Hewan dan Upaya Pelestariannya

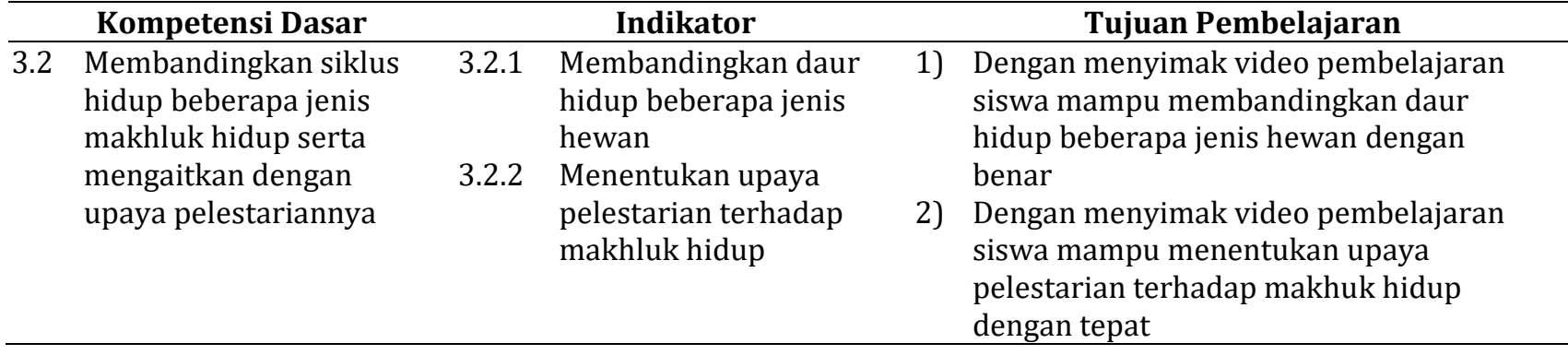

Selanjutnya, analisis media untuk mengembangkan media video pembelajaran kontekstual pada topik daur hidup hewan dan upaya pelestariannya untuk kelas IV SD memenuhi beberapa kriteria yang terdiri dari aspek struktur materi, keakuratan materi, penyajian tata bahasa, penyajian tanda baca, tingkat kesulitan materi dengan pengguna, aspek visual, aspek audio, sajian video, penuangan ide, ketepatan, kejelasan metode, minat/perhatian, dan desain pesan. Tahap kedua yaitu tahap perancangan (design). Media yang dirancang dalam penelitian ini adalah media video pembelajaran kontekstual. Materi yang dimuat dalam video ini yaitu materi muatan IPA topik daur hidup hewan dan upaya pelestariannya kelas IV SD. Proses pembuatan media video pembelajaran ini dibantu dengan menggunakan aplikasi Kine Master sebagai aplikasi utama, dan Microsoft Office Power Point sebagai aplikasi pendukung. Durasi video pembelajaran ini yaitu 12-15 menit dengan rasio 16:9 dan resolusi gambar sebesar 1080 p. Selain itu, video pembelajaran yang dibuat juga ditambahkan dengan backsound dan sound effect agar suasana pembelajaran lebih bersemangat, serta penggunaan baground ketika talent menyajikan materi agar pembelajaran menjadi lebih menarik. Konsep desain/media video pembelajaran tersebut disajikan dalam bentuk naskah dan storyboard. Rancangan naskah berisikan narasi di setiap adegan yang ditampilkan. Sedangkan storyboard video pembelajaran yang dibuat merupakan rancangan skenario media video pembelajaran kontekstual pada topik daur hidup hewan dan upaya pelestariannya untuk kelas IV Sekolah Dasar. Storyboard yang telah dibuat terdiri dari isi video, sketsa tiap scene, dan keterangan. Rancangan storyboard tersaji dalam Tabel 7.

Tahap ketiga yaitu tahap pengembangan (development). Pada tahap ini dilakukan dengan membuat produk awal yaitu media video pembelajaran sesuai dengan naskah dan storyboard yang telah dirancang. Bagian pembuka video menampilkan salam pembuka, identitas pengembang, judul materi serta menampilkan kompetensi belajar, kemudian dilanjutkan dengan ucapan salam dari narator, pengenalan materi yang akan dipelajari, dan pemberian apersepsi untuk menggali pengetahuan awal siswa. Pada bagian isi terdapat penjelasan materi daur hidup hewan dan upaya pelestariannya yang disjikan secara kontekstual seperti menampilkan gambar nyata tentang daur hidup hewan dan memberikan pertanyaan yang bermuatan masalah kontekstual. Bagian penutup pembelajaran terdapat kesimpulan materi, pemberian tindak lanjut untuk siswa 
untuk mengetahui daya serap siswa setelah mempelajari materi, serta salam penutup. Tampilan bagian pembuka, isi dan penutup video pembelajaran kontekstual tersaji dalam Tabel 8.

Tabel 7. Storyboard Media Video Pembelajaran Kontekstual

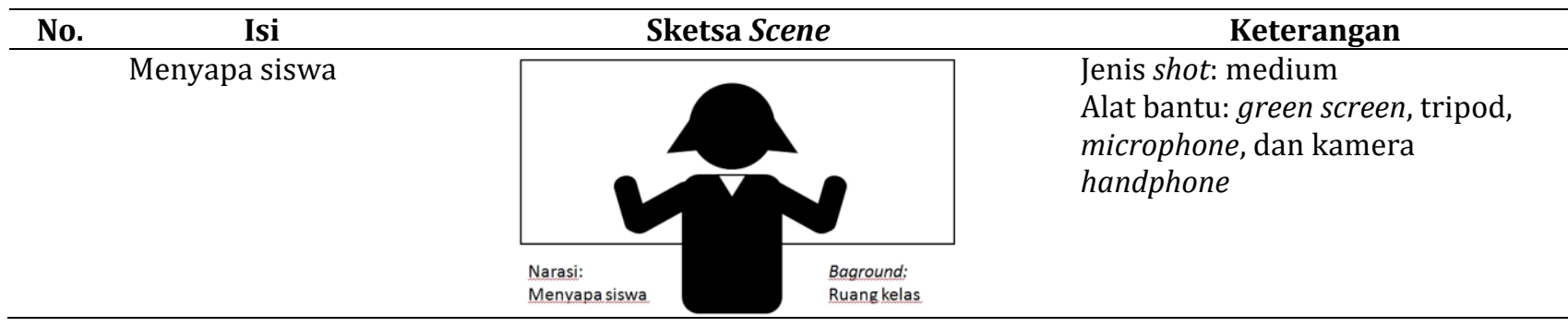

Tabel 8. Produk Awal Medi Video Pembelajaran Kontekstual

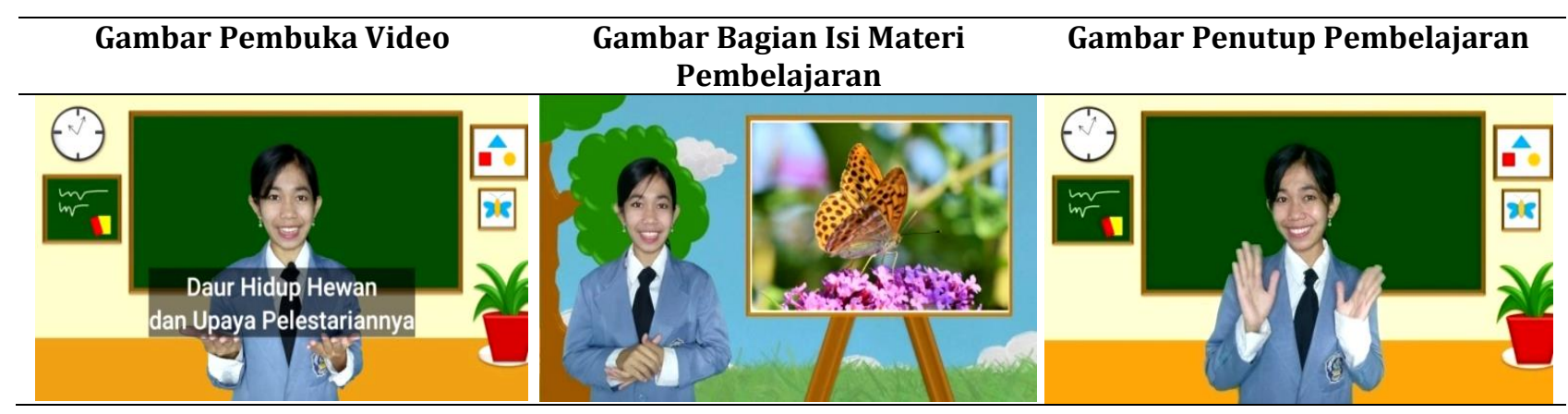

Setalah dilakukan pengembangan media video pembelajaran, selanjutnya dilakukan uji validitas produk untuk mengetahui validitas dari media yang dikembangkan. Uji validitas media video pembelajaran ini dilaksanakan dengan memberikan instrument penilaian kepada dua ahli isi mata pelajaran, serta dua orang media dan desain pemelajaran, dua orang praktisi, dan delapan belas orang siswa yang digunakan sebagai uji coba perorangan dan uji coba kelompok kecil. Data hasil uji validitas produk kemudian dianalisis dengan menghitung rata-rata skor yang diperoleh dari instrument penilaian para ahli, praktisi, dan siswa. Skor rata-rata yang diperoleh kemudian dikonversikan ke dalam pedoman konversi skala lima untuk mengetahui kualitas media yang dikembangkan. Hasil uji validitas media video pembelajaran kontestual pada topik daur hidup hewan dan upaya pelestariannya tersaji dalam Tabel 9.

Tabel 9. Hasil Analisis Uji Validitas Media Video Pembelajaran Konteksrual

\begin{tabular}{clcc}
\hline No. & \multicolumn{1}{c}{ Subjek Uji Coba } & Hasil Validasi & Kualifikasi \\
\hline 1. & Uji Ahli Isi Mata Pelajaran & 3,8 & Sangat Baik \\
2. & Uji Ahli Media Pembelajaran & 3,83 & Sangat Baik \\
3. & Uji Ahli Desain Pembelajaran & 3,67 & Sangat Baik \\
3. & Uji Praktisi & 3,94 & Sangat Baik \\
4. & Uji Coba Perorangan & 3,95 & Sangat Baik \\
5. & Uji Coba Kelompok Kecil & 3,81 & Sangat Baik \\
\hline
\end{tabular}

Berdasarkan data Tabel 8, dapat diketahui bahwa rata-rata skor yang diperoleh dari ahli isi mata pelajaran yaitu 3,8 dengan kualifikasi sangat baik, rata-rata skor yang diperoleh dari ahli media pembelajaran yaitu 3,83 dengan kualifikasi sangat baik, rata-rata skor yang diperoleh dari ahli desain pembelajaran yaitu 3,67 dengan kualifikasi sangat baik, rata-rata skor dari praktisi yaitu 3,94 dengan kualifikasi sangat baik, selanjutnya hasil uji coba perorangan memperoleh rata-rata skor sebesar 3,95 dengan kualifikasi sangat baik, dan hasil uji coba kelompok kecil memperoleh rata-rata skor sebesar 3,81 dengan kualifikasi sangat baik. Sehingga, secara keseluruhan validitas media video pembelajaran pada topik daur hidup hewan dan upaya pelestariannya berada pada rentang 3,25 $<\bar{x}<4,00$ dengan kualifikasi sangat baik. Saat melaksankan uji validitas produk didapatkan juga review dari para ahli isi mata pelajaran, media, dan desain berupa masukan dan komentar guna kesempurnaan produk. Adapun saran, masukan dan komentar yang diperoleh guna memperbaiki produk disajikan pada Tabel 10. 
Tabel 10. Saran dan Komentar Uji Validitas Produk

\begin{tabular}{cl}
\hline No. & \multicolumn{1}{c}{ Masukan, Saran, dan Komentar } \\
\hline 1. & Indikator kedua diubah menjadi "menentukan". \\
2. & Judul memakai huruf capital \\
3. & Beberapa materi seperti manfaat hewan dan tumbuhan, upaya pelestariannya perlu ditambahkan \\
& gambar ilustrasi agar menarik dan mudah dipahami oleh anak. \\
4. & Perlu memberikan penekanan dalam bentuk perbedaan warna pada konsep-konsep yang dianggap \\
& penting \\
5. & Penayangan tujuan dan evalusia durasinya diperlama lagi sedikit \\
6. & Perlu adanya rangkuman materi. \\
\hline
\end{tabular}

Berdasarkan uji validitas produk yang telah dilakukan, didapatkan hasil bahwa media video pembelajaran kontektsua pada topik daur hidup hewan dan upaya pelestariannya untuk kelas IV SD baik dari segi isi, media dan desain pembelajaran memperoleh rata-rata skor yang berada pada rentang $3,25<\bar{x}<4,00$ dengan kualifikasi sangat baik, sehingga dapat diketahui bahwa media video pembelajaran kontektsua pada topik daur hidup hewan dan upaya pelestariannya untuk kelas IV SD dinyatakan valid dan layak digunakan dalam proses pembelajaran. Media video pembelajaran kontektsua pada topik daur hidup hewan dan upaya pelestariannya ini dikatakan valid dan layak digunakan dalam proses pembelajaran karena terdapat aspek-aspek yang mendukung. Dari segi isi, media video pembelajaran kontekstual struktur materi yang disajikan sudah sesuai dengan kompetensi belajar, materi yang disajikan akurat dan berdasarkan fakta yang ada, tata bahasa yang digunakan sesuai dengan sasaran, serta tingkat kesulitan materi sesuai dengan sasaran. Selanjutnya dari segi media, terdapat aspek-aspek yang mendukung yaitu apek visual yang terdiri dari gambar yang ditampilkan dalam media video pembelajaran kontekstual sangat jelas dan sesuai. Penggunaan gambar yang tepat dan sesuai akan dapat mengkonkritkan materi yang bersifat abstrak, mendekatkan dengan objek yang sebenarnya, serta memperjelas suatu masalah (Armansyah et al., 2019; Sari \& Putri, 2018). Animasi yang ditampilkan dalam media video pembelajaran kontektual juga sangat menarik. Kemenarikan animasi yang ditampilkan dalam media video dapat membangkitkan motivasi belajar siswa (Arif et al., 2019; Rosmiati, 2019). Teks yang ditampilkan dalam media video pembelajaran kontekstual dapat terbaca dengan baik oleh siswa serta media video pembelajaran kontekstual memiliki resolusi yang bagus. Dengan menggunakan resolusi yang bagus, maka ilustrasi yang ada dalam video pembelajaran akan dapat terlihat dengan jelas (Riyana, 2007). Aspek audio yang ditampilkan seperti suara narator, sound effect, dan backsound dalam media video pembelajaran jelas dan sesuai. Penggunaan musik dan efek suara merupakan bagian penting dari video karena akan membuat video menjadi lebih menarik, dramatis, dan memberikan kesan yang lebih nyata jika suaranya mendukung dan sesuai (Limbong et al., 2020; Sulihin et al., 2020). Selain itu, penyajian pesan dalam video pembelajaran kontekstual sangat kreatif dan menarik. Media pembelajaran yang menarik akan mampu mengatasi rasa bosan, menumbuhkan sikap positif siswa terhadap materi dan proses pembelajaran, serta dapat meningkatkan kualitas belajar siswa. (Budiono, 2018; Winarto et al., 2020). Kemudian, dari segi desain media video pembelajaran kontestual dalam penelitian ini sudah sesuai dengan karakteristik siswa kelas IV dan karakteristik materi yang disajikan. Bahasa yang digunakan dalam media video pembelajaran kontekstual juga mudah dipahami siswa. Penggunaan bahasa yang sederhana akan memudahkan siswa memahami materi pelajaran, serta penggunaan bahasa yang tepat dapat berpengaruh terhadap pemahaman siswa terhadap suatu konsep dan akan berdampak pada ketertarikan siswa dalam menyimak video pembelajaran (Bigelow et al., 2021; Jundu et al., 2020). Media video pembelajaran kontekstual ini juga mampu membantu siswa memahami materi pelajaran karena penggunaan video dalam proses pembelajaran melibatkan lebih dari satu panca indra serta mampu mengkonkritkan materi yang bersifat abstrak, sehingga materi akan lebih mudah diserap dan dipahami oleh siswa (Busyaeri et al., 2016; Hidayati et al., 2019).

Hal ini sejalan dengan temuan penelitian sebelumnya yang menyatakan bahwa media video pembelajaran kontekstual dapat membantu siswa memahami konsep IPA dasar dan meningkatkan hasil belajar siswa. (Jundu et al., 2020; Nanda et al., 2017). Media video layak digunakan sebagai media pembelajaran dan efektif untuk meningkatkan hasil belajar siswa pada materi daur hidup hewan (Elsani et al., 2019; Riani \& Sulistiowati, 2018). Temuan penelitian lainnya juga menyatakan bahwa penggunaan media video mampu memberikan gambaran nyata bagi peserta didik dalam memahami masalah yang akan mereka pecahkan (Palupi, 2020). Video game dapat memberikan efek positif terhadap motivasi dan hasil belajar siswa sekolah dasar (Sun \& Gao, 2016). Penggunaaan video pembelajaran dapat mempengaruhi pola tingkah laku siswa dalam pembelajaran online (Yoon et al., 2021). Video pembelajaran dapat meningkatkan pemahaman siswa terhadap materi pelajaran serta memotivasi siswa dalam belajar (Andriyani \& Suniasih, 2021; Nurdin et al., 2019). Kelebihan media video pembelajaran kontekstual pada topik daur hidup hewan ini yaitu disajikan secara menarik, materi dikaitkan dengan kehidupan nyata siswa sehingga membantu siswa memahami materi pelajaran, serta disajikan dengan bermuatan masalah kontekstual. Selain itu, media video pembelajaran dalam 
penelitian ini juga memberikan ajakan-ajakan untuk menjaga tumbuhan dan hewan yang ada dilingkungan sekitar, sehingga secara tidak langsung dengan menyimak media video pembelajaran ini selain dapat memahami suatu konsep secara nyata, juga dapat menumbuhkan kesadaran akan pentingnya menjaga hewan dan lingkungan. Kontribusi penelitian pengembangan ini yaitu memberikan inovasi cara mengajar guru dalam mengajar yakni dengan memberikan media pembelajaran yang inovatif dan dapat digunakan dalam proses pembelajaran luring maupun daring, sehingga guru tidak lagi menggunakan metode konvensional dalam mengajar. Implikasi penelitian ini yaitu media video pembelajaran kontekstual dapat digunakan untuk membantu guru dalam menyampaikan materi secara lebih jelas dan menarik, serta dapat membantu siswa dalam memahami materi pelajaran secara nyata. Keterbatasan penelitian ini yaitu karena adanya pandemi Covid-19 tahap implementasi dan evaluasi tidak dapat dilakukan, serta pengembangan media ini hanya dilakukan sampai validitas produk. Oleh karena itu, disarankan kepada peneliti lain agar melakukan penelitian lanjutan untuk mengetahui keefektivan video pembelajaran dilapangan, serta direkomendasikan kepada pendidik agar menggunakan video pembelajaran kontekstual sebagai media pembelajaran untuk membantu siswa memahami materi pelajaran di masa pandemic.

\section{SIMPULAN}

Media video pembelajaran kontekstual pada topik daur hidup hewan dan upaya pelestariannya untuk kelas IV SD dinyatakan valid dan layak digunakan dalam proses pembelajaran. Media video pembelajaran kontekstual ini dapat digunakan untuk membantu guru dalam menyampaikan materi khususnya pada topik daur hidup hewan dan upaya pelestariannya secara jelas dan menarik, serta membantu siswa memahami materi pelajaran khususnya pada topik daur hidup hewan dan upaya pelestariannya secara nyata.

\section{DAFTAR PUSTAKA}

Abidah, A., Hidaayatullaah, H. N., Simamora, R. M., Fehabutar, D., \& Mutakinati, L. (2020). The Impact of Covid-19 to Indonesia, Education and Relation to The Philosophy of "Merdeka Belajar." Studies in Philosophy of Science and Education, 1(1), 38-49. https://doi.org/10.46627/sipose.v1i1.9.

Agustini, K., \& Ngarti, J. G. (2020). Pengembangan Video Pembelajaran untuk Meningkatkan Motivasi Belajar Siswa Menggunakan Model R \& D. Jurnal Ilmiah Pendidikan Dan Pembelajaran, 4(1), $62-78$. https://ejournal.undiksha.ac.id/index.php/JIPP/article/download/18403/14752.

Alessi, S. M., \& Trollip, S. R. (2001). Multimedia for Learning: Methods and Developmen. Pearson Education.

Andriyani, N. L., \& Suniasih, N. W. (2021). Development of Learning Videos Based on Problem-Solving Characteristics of Animals And Their Habitats Contain in Science Subjects on 6th-Grade. Journal of Education Technology, 5(1), 37-47. http://dx.doi.org/10.23887/jet.v5i1.32314.

Apriansyah, M. R., Sambowo, K. A., \& Maulana, A. (2020). Pengembangan Media Pembelajaran Video Berbasis Animasi Mata Kuliah Ilmu Bahan Bangunan di Program Studi Pendidikan Teknik Bangunan Fakultas Teknik Universitas Negeri Jakarta. Jurnal Pendidikan Teknik Sipil, 9(1), 9-18. https://doi.org/10.21009/jpensil.v9i1.12905.

Arif, M. F., Praherdhino, H., \& Adi, E. P. (2019). Pengembangan Video Pembelajaran IPA Materi Gaya untuk Siswa Sekolah Dasar. Jurnal Kajian Teknologi Pendidikan, 2(4), 329-335. http://journal2.um.ac.id/index.php/jktp/article/view/10155.

Armansyah, F., Sulton, \& Sulthoni. (2019). Multimedia Interaktif sebagai Media Visualisasi Dasar-Dasar Animasi. Jurnal Kajian Teknologi Pendidikan, 2(3), 224-229. https://doi.org/10.17977/um038v2i32019p224.

Arsyad, A. (2011). Media Pembelajaran. PT. Rajagrafindo Persada.

Asmuni. (2020). Problematika Pembelajaran Daring di Masa Pandemi Covid-19 dan Solusi Pemecahannya. Jurnal Paedagogy: Jurnal Penelitian Dan Pengembangan Pendidikan, 7(4), 281-288. https://doi.org/10.33394/jp.v7i4.2941.

Baber, H. (2021). Modelling the Acceptance of e-learning during the pandemic of COVID-19-A Study of Sounth Korea. The International Journal of Management Education, 19(2). https://doi.org/10.1016/j.ijme.2021.100503.

Baharuddin, I. (2020). Pembelajaran Bermakna Berbasis Daring Ditengah Pandemi Covid-19. 5(2), 79-88. https://doi.org/10.24256/kelola.v5i2.1377.

Basar, A. M. (2021). Problematika Pembelajaran Jarak Jauh Pada Masa Pandemi Covid-19. Edunesia: Jurnal Ilmiah Pendidikan, 2(1), 208-218. https://doi.org/10.51276/edu.v2i1.112.

Batubara, B. M. (2021). The Problems of the World of Education in the Middle of the Covid-19 Pandemic. Budapest International Research and Critics Institute (BIRCI-Journal): Humanities and Social Sciences, 4(1), 450-457. https://doi.org/10.33258/birci.v4i1.1626.

Bigelow, F. J., Clark, G. M., Lum, J. A. G., \& Enticott, P. G. (2021). The Mediating Effect of Language on the Development of Cognitive and Affective Theory of Mind. Journal of Experimental Child Psychology, 209, 
105158. https://doi.org/10.1016/j.jecp.2021.105158.

Budiono. (2018). Use of Learning CD Media to Improve Student Motivation and Mathematics Learning Outcomes. Formatif: Jurnal Ilmiah Pendidikan MIPA, 8(2), 101-110. https://doi.org/10.30998/formatif.v8i2.2459.

Busyaeri, A., Udin, T., \& Zaenuddin, A. (2016). Pengaruh Penggunaan Video Pembelajaran terhadap Peningkatan Hasil Belajar Mapel IPA di Min Kroya Cirebon. Jurnal Al Ibtida, 3(1). https://doi.org/10.24235/al.ibtida.snj.v3i1.584.

Damayanthi, A. (2020). Efektivitas Pembelajaran Daring di Masa Pandemi Covid-19 pada Perguruan Tinggi Keagamaan Katolik. Jurnal Teknologi Pendidikan, 19(3), 53-56. http://sosial.unmermadiun.ac.id/index.php/sosial/article/view/61.

Dhawan, S. (2020). Online Learning: A Panacea in the Time of COVID-19 Crisis. Journal of Educational Technology Systems, 49(1), 5-22. https://doi.org/10.1177/0047239520934018.

Elsani, S., Nugraha, A., \& Suryana, Y. (2019). Pengaruh Penggunaan Media Video Pembelajaran Siklus Hidup Hewan terhadap Hasil Belajar Siswa pada Siswa Kelas IV SDN Mugarsari. Metaedukasi, 2, 26-32. https://doi.org/10.37058/metaedukasi.v2i2.2511.

Fadillah, A., Dewi, N. P. L. C., Ridho, D., Nurkholis, A., Majid, \& Prastiwi, M. N. B. (2017). The effect of application of contextual teaching and learning (CTL) model-based on lesson study with mind mapping media to assess student learning outcomes on chemistry on colloid systems. International Journal of Science and Applied Science: Conference Series, 1(2), 101-108. https://doi.org/10.20961/ijsascs.v1i2.5128.

Fauzi, H. A., Komalasari, K., \& Malik, Y. (2017). Utilization of Audio Visual Media to Improve Student Learning Result in IPS Learning. International Journal Pedagogy of Social Studies, 2(1), 88. https://doi.org/10.17509/ijposs.v2i1.8666.

Giatman, M., Siswati, S., \& Basri, I. Y. (2020). Online Learning Quality Control in the Pandemic Covid-19 Era in Indonesia. Journal of Nonformal Education, 6(2), $168-175$. https://journal.unnes.ac.id/nju/index.php/jne.

Hidayah, P., Untari, M. F. A., \& Wardana, M. Y. S. (2018). Pengembangan Media Sepeda (Sistem Peredaran Darah) dalam Pembelajaran IPA di Sekolah Dasar. International Journal of Elementary Education, 2(4), 306. https://doi.org/10.23887/ijee.v2i4.16109.

Hidayati, A. S., Adi, E. P., \& Praherdhiono, H. (2019). Pengembangan Media Video Pembelajaran untuk Meningkatkan Pemahaman Materi Gaya Kelas IV di SDN Sukoiber 1 Jombang. JINOTEP : Jurnal Inovasi Dan Teknologi Pembelajaran, 6(1), 45-50. https://doi.org/10.17977/um031v6i12019p045.

Ismiyanti, N. (2020). Perancangan Pembelajaran IPA Menggunakan Software Videoscribe. Vektor: Jurnal Pendidikan IPA, 1(2), 50-58. https://doi.org/10.35719/vektor.v1i2.11.

Jampel, I. N., \& Puspita, K. R. (2017). Peningkatan Hasil Belajar Siswa Sekolah Dasar melalui Aktivitas Pembelajaran Mengamati Berbantuan Audiovisual. International Journal of Elementary Education, 1(3), 197. https://doi.org/10.23887/ijee.v1i3.10156.

Jundu, R., Nendi, F., Kurnila, V. S., Mulu, H., Ningsi, G. P., \& Ali, F. A. (2020). Pengembangan Video Pembelajaran IPA Berbasis Kontekstual di Manggarai untuk Belajar Siswa pada Masa Pandemic Covid-19. LENSA (Lentera Sains): Jurnal Pendidikan IPA, 10(2), 63-73. https://doi.org/10.24929/lensa.v10i2.112.

Khairani, M., Sutisna, \& Suyanto, S. (2019). Studi Meta-Analisis Pengaruh Video Pembelajaran terhadap Hasil Belajar Peserta Didik. Jurnal Biolokus, 2(1), 158. https://doi.org/10.30821/biolokus.v2i1.442.

Lapitan, L. D., Tiangco, C. E., Sumalinog, D. A. G., Sabarillo, N. S., \& Diaz, J. M. (2021). An Effective Blended Online Teaching and Learning Strategy During the COVID-19 Pandemic. Education for Chemical Engineers, 35, 116-131. https://doi.org/10.1016/j.ece.2021.01.012.

Makovec, D. (2018). The Teacher's Role and Professional Development. International Journal of Cognitive Research in Science, Engineering and Education, 6(2), 33-45. https://doi.org/10.5937/ijcrsee1802033M.

Mastura, \& Santaria, R. (2020). Dampak Pandemi Covid-19 terhadap Proses Pengajaran bagi Guru dan Siswa. Jurnal Studi Guru Dan Pembelajaran, 3(2). https://doi.org/10.30605/jsgp.3.2.2020.293.

Mishra, L., Gupta, T., \& Shree, A. (2020). Online Teaching-Learning in Higher Education during Lockdown Period of COVID-19 Pandemic. International Journal of Educational Research Ope, 1, 100012. https://doi.org/10.1016/j.ijedro.2020.100012.

Muamanah, H., \& Suyadi. (2020). Pelaksanaan Teori Belajar Bermakna David Ausubel dalam Pembelajaran Pendidikan Agama Islam. Jurnal Pendidikan Islam, 5(01), 161-180. https://doi.org/10.29240/belajea.v5.

Nanda, K. K., Tegeh, I. M., \& Sudarma, I. K. (2017). Pengembangan Video Pembelajaran Berbasis Pendekatan Kontekstual Kelas V di SD Negeri 1 Baktiseraga. Jurnal Edutech Universitas Pendidikan Ganesha, 5(1), 8899. http://dx.doi.org/10.23887/jeu.v5i1.20627.

Nawas, A. (2018). Contextual Teaching and Learning (CTL) Approach through REACT strategies on improving the students' critical thinking in writing. International Journal of Management and Applied Science, 4(7). https://digital.library.adelaide.edu.au/dspace/handle/2440/124867.

Novita, L., Sukmanasa, E., \& Pratama, M. Y. (2019). Penggunaan Media Pembelajaran Video terhadap Hasil Belajar Siswa SD. Indonesian Journal of Primary Education, 3(2), 64-72. 
https://doi.org/10.17509/ijpe.v3i2.22103.

Nurdin, E., Ma'aruf, A., Amir, Z., Risnawati, R., Noviarni, N., \& Azmi, M. P. (2019). Pemanfaatan Video Pembelajaran Berbasis Geogebra untuk Meningkatkan Kemampuan Pemahaman Konsep Matematis Siswa SMK. Jurnal Riset Pendidikan Matematika, 6(1), https://doi.org/10.21831/jrpm.v6i1.18421.

Pal, D., \& Patra, S. (2020). University Students' Perception of Video-Based Learning in Times of COVID-19: A TAM/TTF Perspective. International Journal of Human-Computer Interaction, 37(10), 903-921. https://doi.org/10.1080/10447318.2020.1848164.

Palupi, B. S. (2020). Penggunaan Video Untuk Meningkatkan Pembelajaran Berbasis Masalah pada Sekolah Didik Sekolah Dasar Kelas Empat. Jurnal BELAINDIKA (Pembelajaran Dan Inovasi Pendidikan), 02(02), 34-41. https://belaindika.nusaputra.ac.id/article/view/54.

Pamungkas, A. S., Ihsanudin, Novaliyosi, \& Yandari, I. A. V. (2018). Video Pembelajaran Berbasis Sparkol Videoscribe: Inovasi pada Perkuliahan Sejarah Matematika. Prima: Jurnal Pendidikan Matematika, 2(2), 127. https://doi.org/10.31000/prima.v2i2.705.

Potdevin, F., Vors, O., Huchez, A., Lamour, M., Davids, K., \& Schnitzler, C. (2018). How Can Video Feedback be Used in Physical Education to Support Novice Learning in Gymnastics? Effects on Motor Learning, SelfAssessment and Motivation. Physical Education and Sport Pedagogy, 23(6), 559-574. https://doi.org/10.1080/17408989.2018.1485138.

Riani, H. R., \& Sulistiowati. (2018). Pengembangan Media Video Animasi Pembelajaran Materi Daur Hidup Hewan pada Siswa Kelas IV di SDN Lakarsantri II/473 Surabaya. Jurnal Mahasiswa Teknologi Pendidikan, 9(2). https://jurnalmahasiswa.unesa.ac.id/index.php/jmtp/article/view/27915.

Riyana, C. (2007). Pedoman Pengembangan Media Video (P3AUIPI (ed.)).

Rosmiati, M. (2019). Animasi Interaktif Sebagai Media Pembelajaran Bahasa Inggris Menggunakan Metode ADDIE. Paradigma - Jurnal Komputer Dan Informatika, 21(2), 261-268. https://doi.org/10.31294/p.v21i2.6019.

Sari, M. K., \& Putri, Y. (2018). The Implementation of Using Picture Media on Teaching Present Continuous Tense. Language Circle: Journal of Language and Literature, 13(1). https://doi.org/10.15294/lc.v13i1.16658.

Selvaraj, A., Radhin, V., KA, N., Benson, N., \& Mathew, A. J. (2021). Effect of Pandemic Based Online Education on Teaching and Learning System. International Journal of Educational Development, 85, 102444. https://doi.org/10.1016/j.ijedudev.2021.102444.

Seo, K., Dodson, S., Harandi, N. M., Roberson, N., Fels, S., \& Roll, I. (2021). Active Learning with Online Video: The Impact of Learning Context on Engagement. Computers \& Education, 165, 104132. https://doi.org/10.1016/j.compedu.2021.104132.

Shah, S. S., Shah, A. A., Memon, F., Kemal, A. A., \& Soomro, A. (2021). Online Learning During the COVID-19 Pandemic: Applying the Self-Determination Theory in the 'New Normal.' Revista de Psicodidáctica (English Ed.), 26(2), 168-177. https://doi.org/10.1016/j.psicoe.2020.12.003.

Sopian, A. (2016). Tugas, Peran, Dan Fungsi Guru Dalam Pendidikan. Raudhah Proud To Be Professionals : Jurnal Tarbiyah Islamiyah, 1(1), 88-97. https://doi.org/10.48094/raudhah.v1i1.10.

Sugihartini, N., \& Yudiana, K. (2018). ADDIE sebagai Model Pengembangan Media Instruksional Edukatif (MIE) Mata Kuliah Kurikulum dan Pengajaran. Jurnal Pendidikan Teknologi Dan Kejuruan, 15(2), 277-286. https://doi.org/10.23887/jptk-undiksha.v15i2.14892.

Sulihin, S., Asbar, A., \& Elihami, E. (2020). Developing of Instructional Video Media to Improve Learning Quality and Student Motivation. EDUMASPUL: Jurnal Pendidikan, 4(2), 51-55. https://ummaspul.ejournal.id/maspuljr/article/view/692/346.

Sun, H., \& Gao, Y. (2016). Impact of An Active Educational Video Game on Children's Motivation, Science Knowledge, and Physical Activity. Journal of Sport and Health Science, 5(2), 239-245. https://doi.org/10.1016/j.jshs.2014.12.004.

Susanti, B. (2019). Penggunaan Media Pembelajaran Videoscribe untuk Meningkatkan Motivasi Belajar Siswa Kelas V Madrasah Ibtidaiyah At-Taqwa Pinang Kota Tangerang Tahun 2018. NATURALISTIC: Jurnal Kajian Penelitian Pendidikan Dan Pembelajaran, 387-396. https://doi.org/10.35568/naturalistic.v3i2.399.

Tegeh, I. M., \& Jampel, I. N. (2017). Metode Penelitian Pengembangan Pendidikan. Universitas Pendidikan Ganesha.

Tias, I. W. U. (2017). Penerapan Model Penemuan Terbimbing untuk Meningkatkan Hasil Belajar IPA Siswa Sekolah Dasar. DWIJA CENDEKIA: Jurnal Riset Pedagogik, 1(1), 50-60. https://doi.org/10.20961/jdc.v1i1.13060.

Winarto, W., Syahid, A., \& Saguni, F. (2020). Effectiveness the Use of Audio Visual Media in Teaching Islamic Religious Education. International Journal of Contemporary Islamic Education, 2(1), 81-107. https://doi.org/10.24239/ijcied.vol2.iss1.14.

Yoon, M., Lee, J., \& Jo, I.-H. (2021). Video Learning Analytics: Investigating Behavioral Patterns and Learner 
Clusters in Video-Based Online Learning. The Internet and Higher Education, 50, 100806. https://doi.org/10.1016/j.iheduc.2021.100806.

Yusup, M., Aini, Q., \& Pertiwi, K. D. (2016). Media Audio Visual Menggunakan Videoscribe sebagai Penyajian Informasi Pembelajaran pada Kelas Sistem Operasi. Technomedia Journal, 1(1), 126-138. https://doi.org/10.33050/tmj.v1i1.8. 